\title{
A System for Quality Assessment of Forestry Contractors
}

\author{
Matevž Triplat, Nike Krajnc
}

\begin{abstract}
Skilled contractors are needed to meet the increased demand for wood and to maintain a competitive edge in forestry. The structure of the forest industry has changed significantly. Today's situation favours smaller contractors that are more flexible. Worldwide contractors are important for forest operations, but there is often limited knowledge about how well they fulfil demands about resource efficiency, social responsibility and environmental protection. The aim of this paper is to present the guidelines for the assessment of forestry contractors following sustainability principles and to present a recently developed system. In addition to the requirements for professional competences and legislative obligations, the system proposes a number of additional requirements such as corporate social responsibility, participation in the local community and greater environmental responsibility. The forestry contractor and the certification body sign a cooperation agreement to obtain the expert assessment. The expert assessment is performed by an evaluator authorised by a certification body. A web service has been introduced with the purpose of serving as a communication tool between professional evaluators and forestry contractors, as well as providing a new possibility for forest owners to get direct contact with forestry contractors. The system enables its users to exert influence on the assessment of forestry contractors by assessing the quality of their services. Private forests would greatly benefit from customer feedback information on the service quality. By now, 1584 forest contractors have registered in Slovenia, where $67 \%$ provide the service of cutting and skidding, $8 \%$ provide woodchipper service, $7 \%$ transport of round wood, $5 \%$ cable crane yarding and 4\% fully mechanised harvesting. Until June 2020, 142 forest contractors have gone through the process of quality assessment.
\end{abstract}

Keywords: services, entrepreneurs, sustainability, evaluation, operations, management

\section{Introduction}

Existing European Union policies promote the use of wood as a renewable resource and, as a result, we are witnessing a growing demand in the raw materials industry (Spinelli et al. 2017). At the same time, the forestry sector has undergone several major changes with respect to the business models of large forestry enterprises over the past decades (Drolet and LeBel 2010, Eriksson 2016, Eriksson et al. 2015 Spinelli et al. 2017, Šporčić et al. 2017). While in the past most of the developmental stages in the forestry industry were induced by technological and industrial development, the majority of recent changes appear to be associated with organizational structure. In Sweden, the struc- ture of forestry contractors changed in the period from the 1960s to the 1990s from independent forest contractors to forest companies that owned their own machinery and had directly employed forest workers, to forest workers who were employed by forest companies but had their own machines, and to forest contractors who were totally independent (Eriksson 2016). In 2009, there were 2219 logging contractors in Sweden, and they employed 6337 workers. Less than $4 \%$ were estimated as large-sized (Häggström 2015). At present, the majority of harvesting is done by forest contractors with one or two groups of harvester and forwarder with up to 9 employees (Erlandsson 2016). Through outsourcing, forest companies gain flexibility to balance in the sense of being able to rapidly 
adjust capacity to market changes, and control in the sense of securing capacity and competence (Erlandsson 2013). In Germany, small scale forest contractors predominate in the forest services market. On average, services cover areas smaller than 1000 ha and are carried out locally, at a distance of up to 20 kilometres from where the contractors are based. They often use old mechanization and worn out equipment. A recent analysis of this economic segment in Bavaria, covering $10 \%$ of companies, has shown that the acquisition of work on the market is mainly dependent on the price of services. Thus the quality of the implemented work is falling rapidly regardless of the fact that the state of the forest in which the work is carried out is one of the key issues for sustainable forest management (Borchert and Benker 2015). In Northern Italy, a total survey of forest contractors was conducted. The results show that logging industry is dominated by small-scale contractors, where partnership companies compared to single-owner companies employ fewer people (1.8 vs. 4.8$)$ and have a lower annual harvest $\left(2000 \mathrm{~m}^{3}\right.$ vs. $5200 \mathrm{~m}^{3}$ ) (Spinelli et al. 2013). Authors concluded that further development of forest contractors is limited. Thus, new business models, different from the typical Nordic subcontracting type, need to be introduced. Forest harvesting business performance has traditionally been associated with a quest for productivity and lower operating costs. In the past, most research essentially concentrated on these two parameters, although little is known about the development of forest contractor structures and strategies (Drolet and LeBel 2010, Häggström et al. 2013).

In the European Commission's (2011) document, corporate social responsibility is defined as a concept by which companies incorporate, on a voluntary basis, social and environmental measures into their business as well as into their relationships with stakeholders. According to the ISO26000: 2010 standard, the definition of social responsibility is as follows: Social responsibility is the responsibility of a business or organisation for the influences of its decisions and activities on the society and the environment, which through transparent and ethical conduct contributes to sustainable development, including the society's health and well-being; takes into consideration the stakeholders expectations; is in accordance with valid legislation and international norms of conduct; is incorporated into the entire organisation and implemented in all of its relations (ISO 26000).

The concept of sustainability was introduced in the 1980s, when the World Commission on Environment and Development was asked to formulate $» A$ global agenda for change (Adams 2006). Sustainable development was defined as »development that meets the needs of the present without compromising the ability of future generations to meet their own needs" (United Nations 1987). Another important step towards sustainable forest management was taken in Rio de Janeiro with the adoption of »Forest Principles«, which gave recommendations for conservation and sustainable forestry development (Fischer 1992). At the European level, the process started with the Strasbourg Conference in 1990. »Forest Principles « where adopted and incorporated into the agenda of the Helsinki Conference in 1993. At that time, the Ministerial Conference on Forest Protection in Europe defined sustainable forest management as follows: »Sustainable management means managing and using forests and woodland in a manner and scope that maintains diversity, productivity, regeneration capacity, vitality as well as its ability to fulfil ecological, economic and social functions at local, national and global levels now and in the future without endangering other ecosystems « (Adams 2006). The concept proposed by the World Commission for the Environment and Development was further refined in 2005. For the first time, sustainability was defined by encompassing three substantive pillars: economic, environmental and social (General Assembly 2006). Sustainable management strives to improve the quality of life, while taking into account environmental constraints. It is an opportunity for forestry contractors to introduce socially responsible behaviour into their business models and thus contribute to the society as a whole.

Recently, Marchi et al. (2018) have described the evolving views of sustainability in forest operations and have proposed a contemporary concept of Sustainable Forest Operations, which is based on a broader focus and different scales that reconcile bioeconomy, environmental ecology, human factors and society. In addition to the three pillars of sustainable development, the new paradigm introduced two further aspects, i.e. ergonomics and quality optimisation,

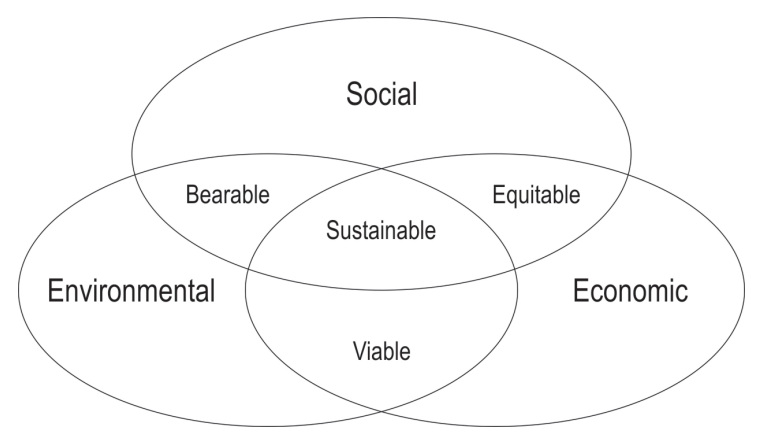

Fig. 1 The principles of sustainability provide the main guidance in the development of the professional rating methodology (Wikipedia 2019) 


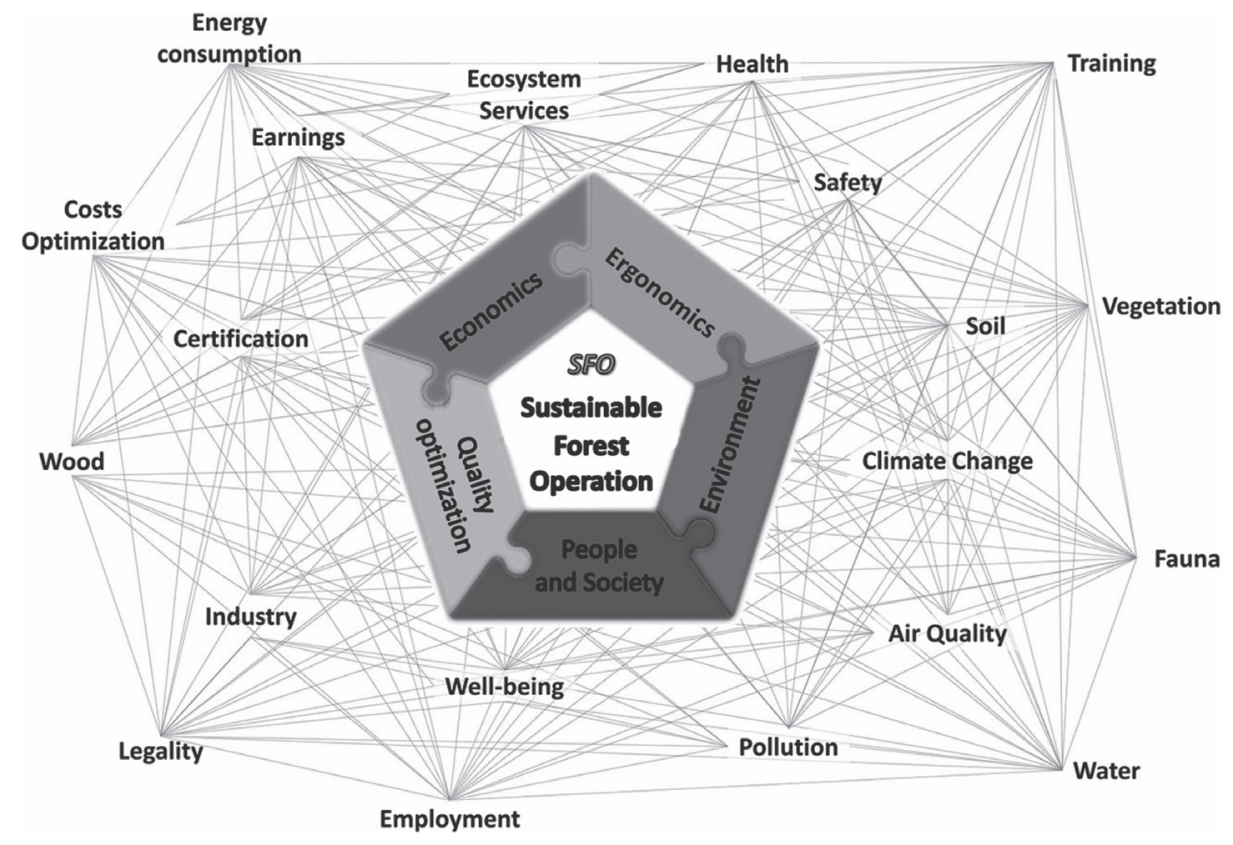

Fig. 2 Complex system of relationships of sustainable forest operations (Marchi et al. 2018)

in sustainable forest operations. The concept is defined as a complex system of relationships between indicators that correspond to the mentioned aspects (Fig. 2). The performance of each aspect strongly affects other aspects in terms of »quantity and quality«.

A team of specialists was set up under the integrated programme of the UNECE Timber Committee and the FAO European Forestry Commission to address this issue. This team, led by Edgar Kastenholz of ENFE, has drawn up a Guide to Good Practice in Contract Labour in Forestry, which is intended to help these contractors, and those working with them, to understand the issues and function in a truly sustainable way. The following model is a summary of the various criteria for good practices that make up the content of this guide. It does not simply explain what the working conditions should be. Instead, it outlines the framework conditions contributing to a good business environment, thereby allowing fair competition and partnerships between forestry contractors and their clients as well as among the contractors themselves (European Commission 2010).

Between 2009 and 2012, a pilot forestry certification process was developed under a European Union funded project called CeFCo. The project tested procedures that would enable small private forest owners to delegate forest management tasks to certified forest contractors. This three-year project was rolled out and tested across five European countries: Bulgaria,
Denmark, Portugal, Spain and Sweden. The project objective was to simplify and facilitate greater access to Forest Stewardship Council (FSC) certification for smallholders, through a new concept where forest managers use certified forestry contractors. The concept reduces costs and workload for forest managers seeking certification (Feil 2009, 2012).

In Sweden, the Elmia Wood forest fair created »The Golden Logger« award in 2011 with the help of Skogforsk. The aim was to recognise a forest contractor who has developed the most innovative and effective way to improve profitability and success in attracting new staff and/or developing existing staff. Aspects considered by the jury include leadership, customer satisfaction, machine strategies and how attractive the company is as an employer (Fogdestam et al. 2013).

Masiero and Andrighetto (2012) have presented guidelines for the evaluation of sustainability in the wood-energy supply chain. The guidelines were created as a basis for a standard that has a multidimensional approach and considers four principles:
$\Rightarrow$ legality and responsibility in social and environ- mental issues
$\Rightarrow$ environmental safeguards
$\Rightarrow$ local development
$\Rightarrow$ economic efficiency.

Šporčić et al. (2017) pointed out the necessity of developing a licensing model that would filter existing 
forestry contractors and ensure quality in performing forest work operations. Authors presented a licensing model implemented in 2007 for forest contractors in Croatia. The licensing model includes formal criteria and minimum conditions that forestry contractors have to fulfil in order to acquire a license for forest work operations. According to the authors, the process of licensing forestry contractors is an important element in every business activity, and in the field of forestry it is a must for providing sustainable forest management. The licensing process puts an emphasis on the inclusion of private contractors in sustainable forest management through a process of certification of their quantitative and qualitative characteristics.

Erlandsson (2016) studied quality perceptions of harvesting services from the perspective of forest owners associations, contractor and forest owner using a multi-dimension approach. The study indicated that individual perceptions strongly influence valued quality factors and dimensions. The study, therefore, suggested a tool for measuring quality perceptions of harvesting services, which enabled the positioning of service relationship success from a logistics triad perspective. Three party relationships were established, where forest owners are represented as service buyers, wood supply organisations as service sellers, and contractors as service providers. The tool was developed to fit the context of forest owner associations with outsourced harvesting services, and to facilitate the analysis of harvesting service relationships from multiple perspectives.

In New Zealand, a contractor certification was developed called »Safetree« (Forest Industry Safety Council 2014). Safetree Contractor Certification was set up by the Forest Industry Safety Council and provides forestry with standardised assessment of forestry contractors and their suitability to work. It is focused on the assessment of health and safety at work. The standards cover several areas: risk management, critical risks, health risks, forest management, competency and others. It is a voluntary system with more than 190 companies certified. To become certified, contractors need to complete an online assessment and a field audit.

Increasingly, forestry operations are carried out by contractors. The use of contractors in forestry is of increasing importance worldwide, and these contractors are subjected to intense competition. In addition, there is a serious lack of cooperation and mutual support structure. These contractors, therefore, face major challenges in terms of occupational health and safety as well as economic viability. The sustainability of forests, wood resources and operations in forestry needs to be assured at all stages of planning and execution of wood mobilisation, with regard to both policies and measures. All approaches should be in line with high standards for resource efficiency, social responsibility and environmental protection (European Commission 2010). Forestry contractors are crucial for efficient and sustainable forest management. Although forestry contractors must take into account the legislation and environmental aspects of forestry work, ultimately this responsibility lies with forest owners. Qualified, motivated and well-informed forestry contractors are a crucial basis for cost-effective and environmentallyfriendly forest management (Belbo 2013).

The aim of this paper is to present the guidelines for the sustainability assessment of forestry contractors following social, environmental and economic principles (Fig. 1), including technical characterisation and expert judgements. The aim is also to describe how assessment was used in developing the certification scheme supported by web-based tool in Slovenia to align forest owners, forest enterprises and contractors and to present the results of the quality assessment. In the following text, forest enterprise refers to a large forest company, while forestry contractor refers to a rather self-employed worker, small or mid-sized logging company, which is usually hired by a large forest company or directly by forest owner.

\section{Materials and Methods}

After an overview of the existing systems for quality assessment of forest contractors, a system for assessing the quality of forestry contractors in Slovenia was developed in several steps:

$\Rightarrow$ development of a list of relevant criteria for quality assessment

$\Rightarrow$ development of a list of indicators for all selected criteria through active participation of stakeholders

$\Rightarrow$ preparation of an unbiased list of indicators and their associated weights for the assessment of forestry contractors using a group analytic hierarchy process (GAHP)

$\Rightarrow$ development of web service called MojGozdar (»MyForester $«)$, which embraces a three-level sustainability assessment of forestry contractors in Slovenia.

\subsection{Legality of Forestry Contractors}

Forestry contractors must be legally checked by the competent forestry inspection authority. According to Slovenian legislation, each contractor is responsible for assuring the professional competences of their work- 
ers and for obtaining the certifications needed for performing various works providing health and safety at work, working equipment and personal protective equipment. On the basis of certifications submitted by forestry contractors, forest inspections regularly update the list of contractors who fulfil the minimum conditions, as well as the list of contractors who received a written order prohibiting their work (IKGLR 2018). Automatic evaluation of forestry contractors was created according to the traffic light principle using several databases, which mainly correspond to the legal status of the forestry contractor, e.g. data on economic activity are collected from the Agency of the Republic of Slovenia for Public Legal Records and Related Services (AJPES), data on tax payments are collected from the Financial Administration of the Republic of Slovenia (FURS) and data on compliance with regulations on minimal professional competences and health and safety at work are collected from the Inspectorate of the Republic of Slovenia for Agriculture, Forestry, Hunting and Fishing (IKGLR). The list of formally suitable forest contractors needs to be regularly updated on the basis of changes occurring in any of the related databases. The system must incorporate all forestry contractors who are registered for performing forestry services (not only those who decide to participate in the quality assessment process). Evaluation of forestry contractor legality according to the traffic light principle is as follows:

$\Rightarrow$ the green light denotes forestry contractors who have fulfilled all requirements during inspection, are not on the list of tax debtors and are legal entities according to the Business Register of Slovenia

$\Rightarrow$ the yellow light denotes forestry contractors that are not on the list of tax debtors, are legal entities according to the Business Register of Slovenia and are registered for relevant activities as per the standard classification of business activities. It should be noted that the yellow light denotes the companies for which no official record is kept by any inspection authority. These are, for example, the contractors providing services associated with wood chip production, wood transport and forestry construction

$\Rightarrow$ the red light is a warning sign that the contractor has been prohibited, by order, from carrying out at least one of the registered forestry activities (the activity that is prohibited is marked separately), or is a tax debtor, or is a non-active legal entity according to the Business Register of Slovenia, or has not registered relevant activities as per the standard classification of business activities.
The legality assessment shall be understood as a minimum requirement that forest contractors have to meet before implementing any sustainability criteria and indicators.

\subsection{Principles for Quality Assessment of Forestry Contractors in Case of Slovenia}

The social principle of sustainable management encompasses responsibility to society with respect to worker rights, worker health and safety, employment of persons with disabilities and personal development of employees. Most often, at the EU level, corporate social responsibility is defined as a concept within which voluntary companies integrate concern for society and the environment into their day-to-day operations and into their relationships with stakeholders (EKVILIB 2019). One aspect of the social pillar of sustainable forest management, which has so far received little attention at the policy level, is the forestry workforce. At the international level, there has been little recognition of the fact that sustainable forestry requires a sustainable work force (Kastenholz et al. 2011).

Forestry service providers have an impact on company organisation and employees, as well as on the environment. Thus, the requirements of environmental laws and regulations must be met, environmental aspects taken into account, and objectives pursued in terms of advances in environmental protection (Knez-Riedl 2008). The environmental principle encompasses the company's responsibility for the environment in the sustainable aspects of forest management, promotion of more environmentally-friendly technologies and respect for environmental constraints.

Economic activities, the patterns of behaviour in production and consumption, and the level of economic development of countries influence the state of the environment, as natural resources are one of the key factors in production processes. All economic activities should contribute to the promotion of sustainable development when making decisions that are economically efficient, socially fair and environmentally friendly (Lukič 2004). The economic principle involves assessing business performance and accountability to the local environment in the area of economic stability and business results, relationships with business partners and involvement of local stakeholders in production.

Despite this new paradigm in sustainable forest operations proposed by Marchi et al. (2018), authors have decided to keep the idea of three principles of sustainability, which are further divided in several criteria. However, a vigilant eye will be able to notice that the criteria and indicators presented within this 


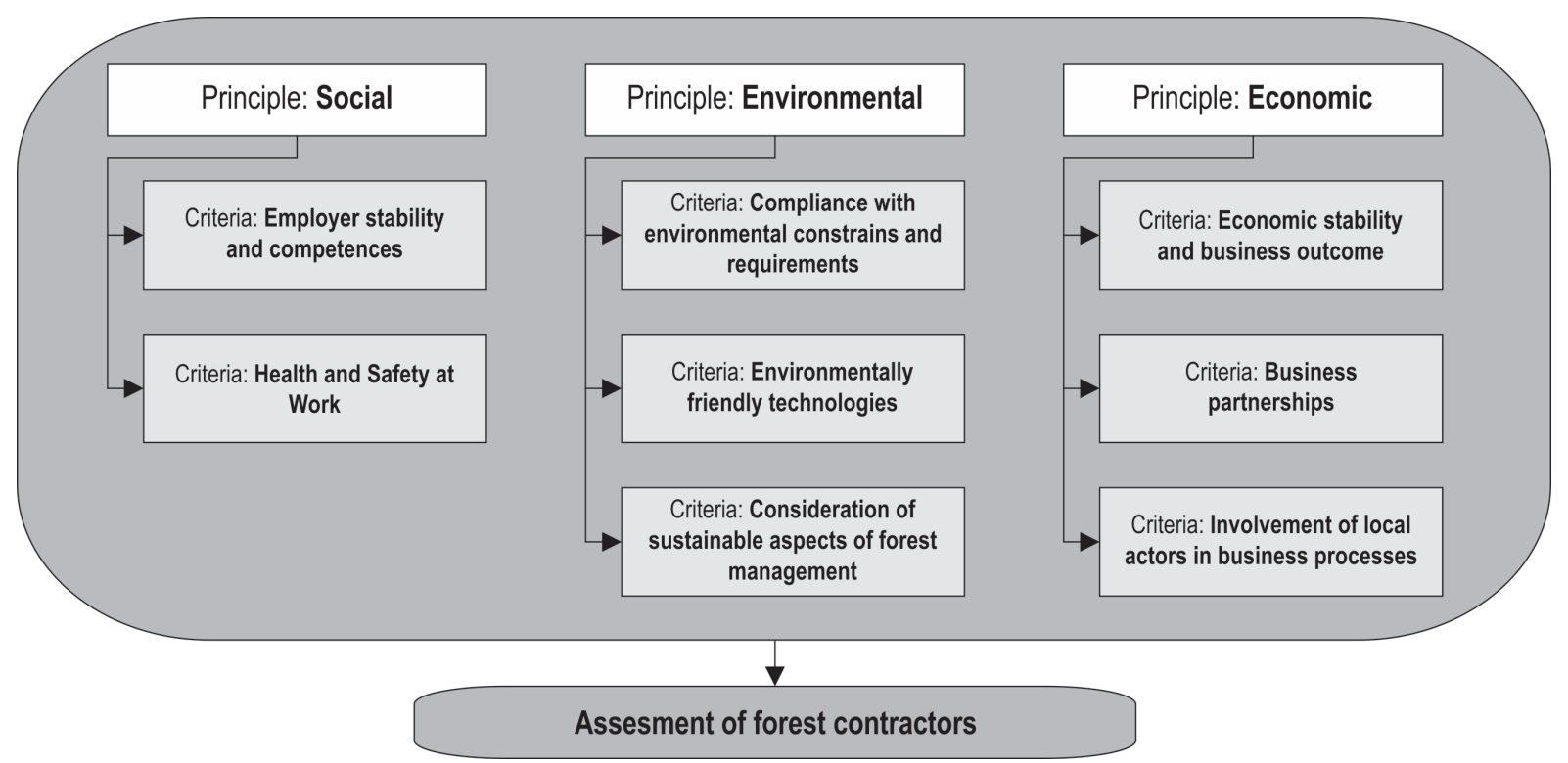

Fig. 3 Principles and criteria for quality assessment of forestry contractors

paper coincide with indicators presented by Marchi et al. (2018). This hierarchy of principles, criteria and indicators is a backbone of developed system of quality assessment of forestry contractors introduced in this article. The principles described in this section are further defined by principle-specific criteria that detail the context of each principle and support its implementation in operational terms. The criteria are described in Fig. 3. The indicators are listed in Table 1.

\subsection{Criteria for Quality Assessment of Forestry Contractors}

\section{Social principle - Health and Safety at Work}

Working conditions in forestry are a very important part of forest-wood supply chains. There are many regulations in the EU regarding health and safety at work, as well as health and safety rules when using work equipment and machines. Proper use of safety equipment and machinery is an essential criterion for preventing accidents at work in forestry. The systematic approach of the business entity and upgrading in the field of preventive activities in the field of health and safety at work are also reflected in measures related to the planning of emergency procedures at the work site, promotion of health during working hours, ability to provide first aid and other activities.

\section{Social principle - Employer stability and competences}

At each stage of the forest-wood supply chain, employees of forestry contractors must, in accordance with the applicable laws, have an employment contract for all activities (from logging to planning). In addition, all individuals involved in the forest-wood supply chain must demonstrate an appropriate level of competence in relation to their role in the supply chain. Motivated, educated and trained staff is a fundamental factor of success in development, quality and competitiveness.

\section{Environmental principle - Compliance with environmental constrains and requirements}

Compliance with environmental regulations ensures an adequate level of environmental protection, while contributing to promoting legality and transparency along the entire forest-wood supply chain. Measures to reduce the invasiveness of timber harvesting technologies are a reflection of the contractor's systematic approach. Such an approach means upgrading regulations in the field of forest protection and performance of works, and affects the quality of work performed in terms of damage to soil and forest infrastructure, while reducing the cost of rehabilitation and maintenance.

\section{Environmental principle - Environmentally friendly technologies}

Forest machines used along the forest-wood supply chain produce emissions that are harmful for the environment, cause air pollution and contribute to global warming. Technological improvements can be used to reduce emissions, lower the consumption of fuel and increase efficiency. Forestry contractors are 
encouraged to modernise their machinery and lower the amount of emissions generated along the supply chain below certain thresholds.

\section{Environmental principle - Consideration of sustainable aspects of forest management}

Environmental issues have become increasingly important in recent years, and their consideration is an important competitive advantage for forestry contractors and a prerequisite for their efficient operation. Modern technology is essential for sustainable forest management. In forest management, negative impacts on the environment should be avoided or eliminated. The aim is to preserve biodiversity while ensuring cost-effective ways of managing natural resources. It is important for forestry contractors to be aware of environmental constraints and to assess and reduce their environmental impact while enhancing competitiveness. In addition, consumers are increasingly seeking evidence of environmentally sound manufacturing processes and are demanding assurances and proof from the manufacturing industry that the wood and raw materials used originate from continuously monitored sources. Forest Stewardship Council (FSC) and Programme for the Endorsement of Forest Certification (PEFC) certifications ensure that the products come from forests that are managed in accordance with internationally defined standards for sustainable management.

\section{Economic principle - Business partnerships}

The correct attitude towards business partners is an important factor of success. Customer relationship management is a business strategy that seeks to gather as much information as possible about customers, their needs and behaviours. Good relations are the basis for mutually beneficial and long-term business cooperation. Forestry contractors can maintain a register of positive and negative customer feedback to obtain useful information for improvement. It is essential for forestry contractors to be aware of the value of any complaint, as this is welcome information that can contribute to better business performance in the long run. Long-term and permanent contracts are also of great importance. Long-term raw material supply contracts ensure economic stability in the supply chain. A long-term contract may also ensure the quality of the supply.

\section{Economic principle - Economic stability and business outcome}

The economic stability of the company ensures greater efficiency, effectiveness and economic benefits of the business. The long-term economic stability of the company fosters greater confidence among clients.

\section{Economic principle - Involvement of local actors in business processes}

Social responsibility presupposes that companies must take into account and involve local actors and the community in their operations. The work of companies must, therefore, be balanced with the expectations, values and norms of stakeholders and the community. The social responsibility of managers and practitioners of organisational communication, that is, public relations, is manifested through a proactive pursuit of a participatory social culture and social good that puts the interests of the community at the forefront (Gole 2015). The active role of various local actors within the forest-wood supply chain can foster a useful exchange of expertise and locally create opportunities for new jobs. In addition, by involving the various actors in the supply chain, they get informed about forest management and, if necessary, actively participate in it. Final$\mathrm{ly}$, the development of new projects concerning the potential supply of natural resources in a particular area can revive the local economy.

\subsection{Indicators (Proof Documents)}

On the basis of a survey of the above mentioned research and coordination workshops with stakeholders, a proposal of indicators for all presented criteria was made. Stakeholder representatives were experts from the Faculty of Forestry (a partner in the project) and other institutions such as the Inspectorate of the Republic of Slovenia for Agriculture, Forestry, Hunting and Fisheries (IKGLR), Chamber of Agriculture and Forestry of Slovenia (KGZS), Institute for Nature Conservation (ZRSVN), the Slovenia Forest Service (ZGS), representatives of major contractors, and representatives of the state-owned forest management company SiDG d.o.o. In total, 20 persons were included (mainly general directors or executive directors, decision-makers, forestry advisors or lobbyists). The final result of workshops with stakeholders was a hierarchical list that embraced three principles, eight criteria and twenty-eight indicators (Table 1). In the second round, an extended group of representatives from all stakeholder interests set measures for the selected principles, criteria and indicators on the basis of methods for multi-criteria decision making (MCDM). The result of the second round was an unbiased list of indicators and their associated weights for the assessment of forestry contractors. The MCDM method used was a group analytic hierarchy process (GAHP). GAHP analysis was done primarily by expert 
interviews. Interviewees were selected from the three main actor groups:

$\Rightarrow$ forestry contractors

$\Rightarrow$ clients (forest owners, forest managers)

$\Rightarrow$ forestry experts (forest scientists, lobbyists, public authorities) as a neutral party.

In total, 80 interviews were conducted in this analysis. A detailed presentation of the MCDM methodology goes beyond the scope of this paper and will be presented in a following paper. Joint weights per indicator are transformed into the points and are presented in the last column of Table 1.

A combined evaluation, which embraces economic, social and environmental aspects, is most suitable for assessing the sustainability of forestry contractors. The total number of possible indicators is 28 . The indicators have a predetermined number of possible points (Table 1). The indicators bring a total of 100 points.
During the assessment, efficient communication between contractors and evaluators is necessary. In Slovenia, a web service called MojGozdar (»MyForester «) was introduced with the purpose of serving as a communication tool between professional evaluators and forestry contractors as well as offering the possibility of communication between customers and forestry contractors (Slovenian Forestry Institute 2017). The MojGozdar system embraces a three-level sustainability assessment of contractors in a simple, transparent and objective manner. The forest contractor completes an online application. Each indicator selected includes a description of the indicator that explains how to interpret and collect evidence. The supporting documents must be uploaded to the online system in the form of scanned documents. Original documents are kept with the forestry contractor. It should be noted that the contractor can select any of the indicators, as no indicator is required. It is up to the contractor to

Table 1 List of principles, criteria and indicators with associated points

\begin{tabular}{|c|c|c|c|}
\hline Principle & Criteria & Indicator & Points \\
\hline \multirow{9}{*}{ Social } & \multirow{5}{*}{ Employer stability and competences } & Professionally qualified workers & 9 \\
\hline & & Periodic professional training of workers & 7 \\
\hline & & Most workers have long-term contracts & 5 \\
\hline & & Quality management (ISO 9001, etc.) & 3 \\
\hline & & Recruitment of disabled people & 2 \\
\hline & \multirow{4}{*}{ Health and safety at work } & Periodic inspection of machines and equipment & 6 \\
\hline & & Ensuring safety in the workplace & 4 \\
\hline & & Register of injuries with implemented measures to avoid future occurrences & 2 \\
\hline & & Promotion of health in the workspace & 2 \\
\hline \multirow{9}{*}{ Environmental } & \multirow{4}{*}{$\begin{array}{l}\text { Compliance with environmental } \\
\text { constrains and requirements }\end{array}$} & Environmental management systems & 4 \\
\hline & & Hazardous waste management & 3 \\
\hline & & Compliance with other environmental constraints and requirements & 3 \\
\hline & & Management of plant protection products & 2 \\
\hline & \multirow{3}{*}{ Environmentally friendly technologies } & Reduced greenhouse gas emissions & 3 \\
\hline & & Use of biodegradable oils or alkylate petrol & 5 \\
\hline & & Use of energy from renewable sources & 2 \\
\hline & \multirow{2}{*}{$\begin{array}{c}\text { Consideration of sustainable } \\
\text { aspects of forest management }\end{array}$} & Sustainable forest management & 5 \\
\hline & & Avoid degradation of forest stands, soils, hydrology and infrastructure & 6 \\
\hline \multirow{10}{*}{ Economic } & \multirow{5}{*}{ Business partnerships } & Compliance with statistical classification of economic activities & 3 \\
\hline & & Disclosure of information regarding the price of services & 4 \\
\hline & & Long-term contracts with customers & 3 \\
\hline & & Customer relationship management & 2 \\
\hline & & Complaint register & 3 \\
\hline & \multirow{3}{*}{ Economic stability and business outcome } & Covering multiple processes in the supply chain & 2 \\
\hline & & Re-investments in fixed assets & 3 \\
\hline & & Added value per employee & 2 \\
\hline & \multirow{2}{*}{$\begin{array}{l}\text { Involvement of local actors } \\
\text { in business processes }\end{array}$} & Collaboration or financial support in local projects & 3 \\
\hline & & Membership in interest associations & 2 \\
\hline
\end{tabular}


decide which ones to submit. The supporting part of the peer review also includes a review and advice on indicators and how to achieve the highest possible score. Notification of the completed application form is sent to the evaluator authorised by MojGozdar, who performs an independent expert evaluation of the application submitted by the provider through the MojGozdar online information system and determines whether the evidence is adequate and determines the suitability assessment for each selected indicator.

Based on the final judgment, a rating (denoted by cones) is assigned according to the independent peer review. The sum of points denotes a composite assessment (from $0-5$ cones). The following boundary values are taken into account:

$\Rightarrow 1$ cone is acquired by a forest contractor who enters data on mechanisation and data on services in the online application for expert assessment

$\Rightarrow 2$ cones are obtained by the forest contractor who scores 20 points

$\Rightarrow 3$ cones are obtained by the forest contractor who scores 30 points

$\Rightarrow 4$ cones are obtained by the forest contractor who achieves 40 points

$\Rightarrow 5$ cones are obtained by the forest contractor who achieves 50 points.

The composite assessment is presented along with other publicly accessible data on legal entities.
The presented system with its principles and criteria has been developed based on the ideas introduced by Masiero and Andrighetto (2012), Marchi et al. (2018) and Adams (2006) and has been further developed and implemented into practice as a web-based tool.

\section{Results}

Until June 2020, in total, 1584 forest contractors were included (Fig. 4) and this number increased on average by 10.2 contractors per month during the last year. From the organisation point of view, small type of forest contractors mainly prevail, $48.7 \%$ of forest contractors are organised as self-employed person (usually employing the owner and a few forest workers). The second largest group with $34.1 \%$ are farmers, which are allowed to register for providing services beside their main business activity (usually agriculture activities). However, the scope of work they can perform, providing services, is limited by law in terms of quantity. The third largest group with $14.6 \%$ are public limited companies, as private legal entities with their own legal identity, which separates the liability of the company from its employees and stakeholders.

\subsection{Sustainability Assessment of Quality of Forestry Contractors in Mojgozdar}

Hereinafter, the evaluation based on different data sources is presented.

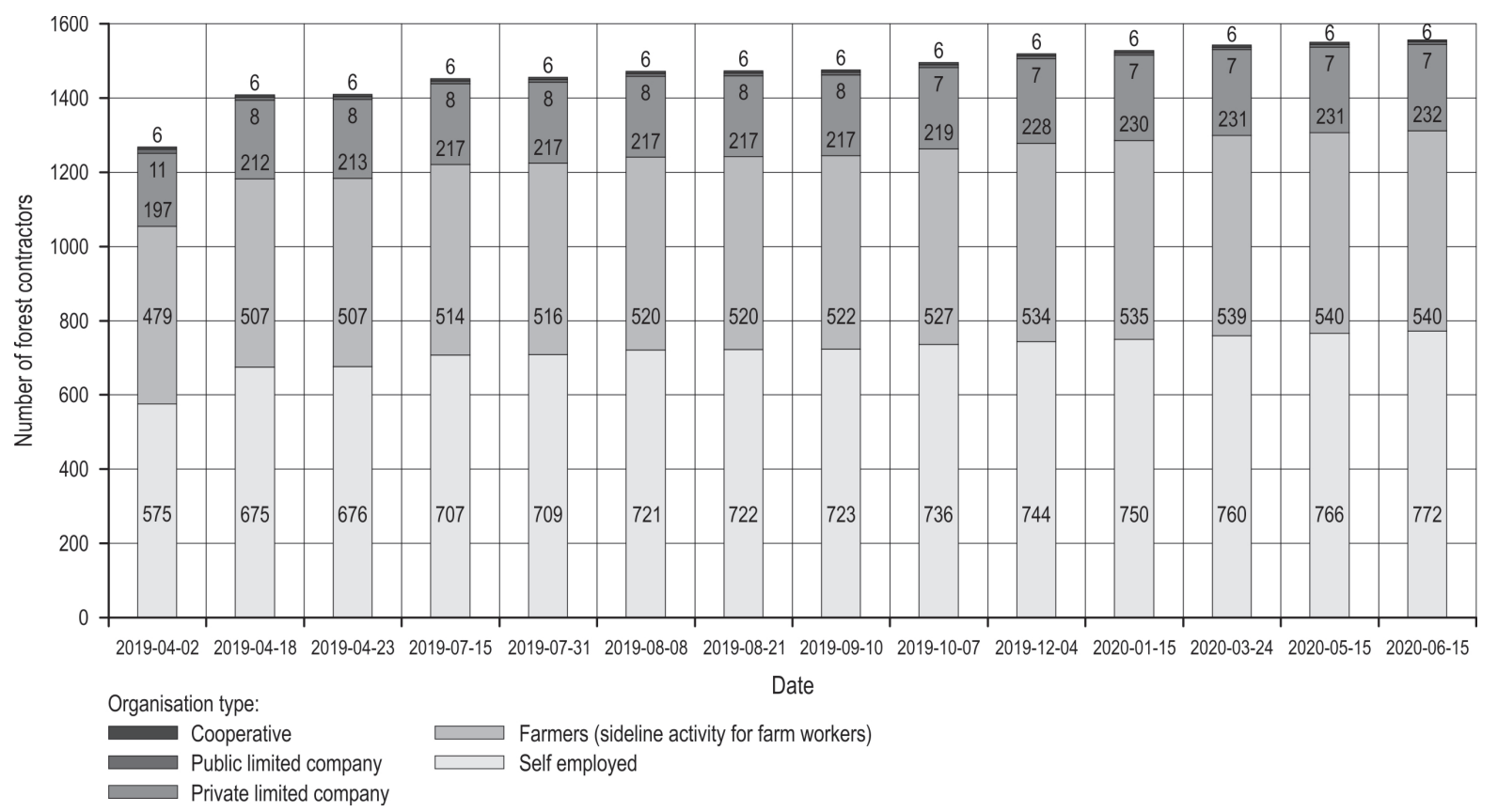

Fig. 4 Organisational structure of forest contractors 


\section{Level 1 - Formal suitability of forestry contractors based on available data sources on business entities}

The results of the first level assessment are presented in Fig. 5. The block chart represents:

$\Rightarrow$ number of suitable forest contractors who fulfil minimum requirements

$\Rightarrow$ contractors who have failed the legality check and during inspection have been prohibited, by order, from doing business

On June 2020, in total, 1372 forest contractors were formally suitable for providing services and $15 \%$ of the registered contractors were prohibited from doing business. The line chart presents the number of suitable contractors per selected forest service. In case of suitable forest contractors, $67 \%$ provide the service of cutting and skidding, $8 \%$ provide woodchipper service, $7 \%$ transport of round wood, $5 \%$ cable crane yarding and $4 \%$ fully mechanised harvesting. On average, public limited companies have 2.1 forest services, private limited companies 1.87 forest services and selfemployed person have 1.24 forest services.

\section{Level 2 - Expert assessment of suitability of forestry contractors}

The second part comprises the methodology for conferring an independent professional rating based on the presented guidelines. All contractors, who are rated as suitable during the first level, can take part in the second level of assessment. The main concept of professional assessment follows the descriptions presented in Section 2. It is important to emphasise that the professional assessment is withdrawn when forestry contractors do not meet the conditions required for the green or yellow light (first level of assessment). Fig. 6 presents the results of expert assessment. Forest contractors, who have volunteered to participate in the second level of assessment, are awarded with one cone score just by reporting the data on services capacity and information on their forest machinery. For a higher score, the forest contractor has to follow the above process of evaluation.

The expert assessment of MojGozdar is awarded for a period of three years. During planned and unannounced annual inspections, the inspection body checks the documentation. The forestry contractor may apply for an extension of the trademark two months before the end of the three-year period. The obligations of the forestry contractor after being awarded the trademark are as follows:

$\Rightarrow$ notify within one month all changes that would cause a change in the categorisation of rating

$\Rightarrow$ update once a year the status of the machinery used to provide the service

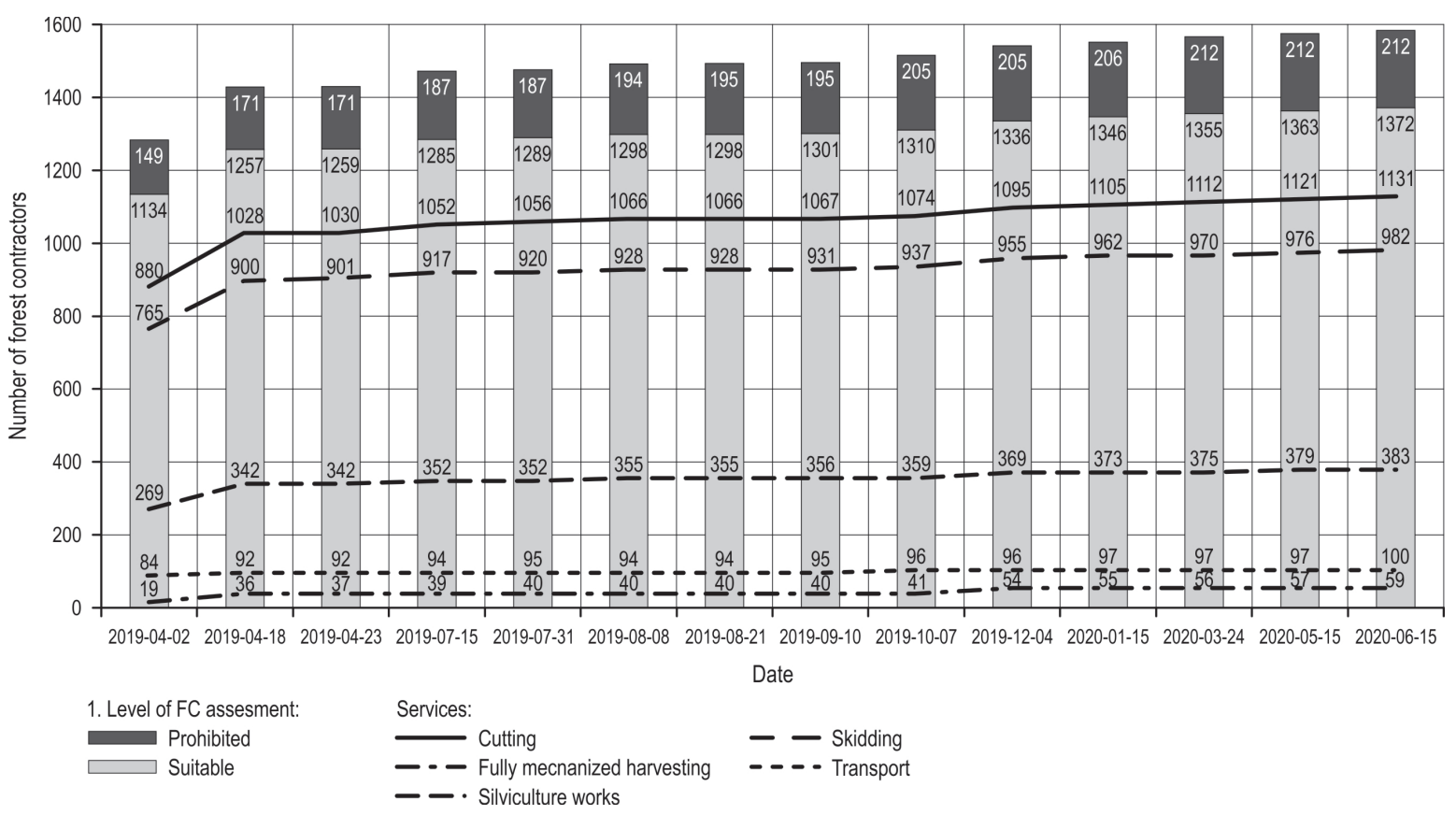

Fig. 5 First level of quality assessment of forestry contractors based on legality (block chart) and number of suitable forest contractor per services (line chart). Each forest contractor can have several services 

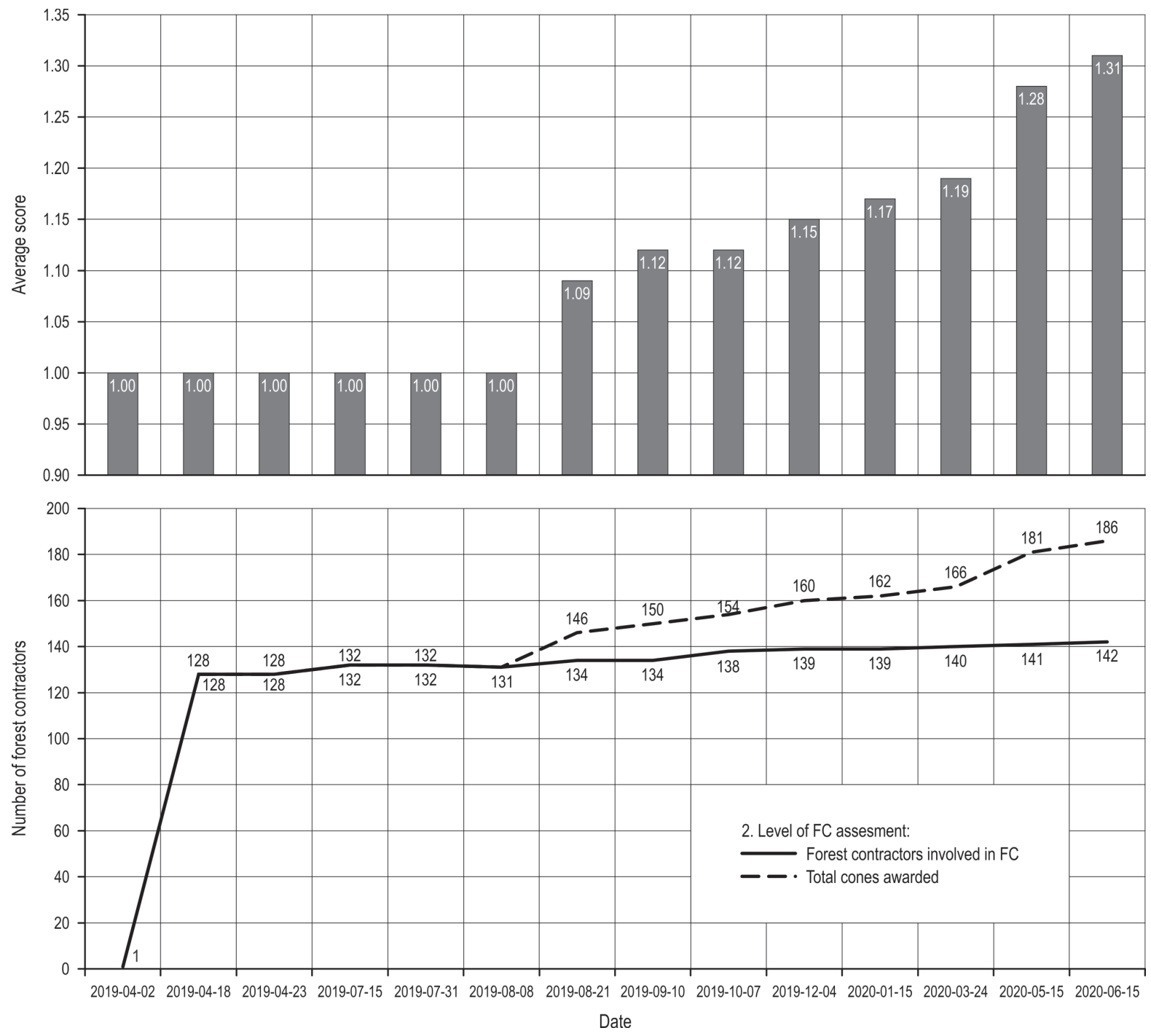

Fig. 6 Second level of quality assessment of forestry contractors based on expert assessment

$\Rightarrow$ report annually on the quantities of services provided through the MojGozdar online information system

$\Rightarrow$ comply with other provisions imposed on the auditor by the compliance report.

\section{Level 3 - Customer rating on service quality}

Reviews and opinions concerning the quality of the carried-out service shall be conveyed by customers. The average rating obtained from the customers shall be part of the quality assessment system as a whole. It would be incorrect to expect a client to give an objective assessment, so it should be borne in mind that the client's assessment is subjective. However, repeated complaints against a particular forestry contractor should alert prospective customers to potential issues. Assessment of the service quality is possible with the use of a short online questionnaire, which is completed by the client or client's representative upon completion of the service. The questionnaire contains an assessment of several aspects of the services provided (e.g. ground, stand and infrastructure condition after performing the services; observance of agreement and agreed time limits; agreement clarity; and price deviation). After the client assessment, the forestry contractor must be informed of the assessment to have the opportunity to respond to individual assessments that are less favourable, if he considers them to be untrue and unfair. However, on the basis of the contractor's complaint, the customer must provide evidence of cooperation with the evaluated forestry contractor. The maximum rate that can be given by customers is 10 . The obtained rating is recorded in the system and based on 80 ratings the average rate is 8.5 . 


\section{Discussion}

The system for the quality assessment of forestry contractors is a process that establishes a higher level of requirements for forest contractors. According to the present organisation of forestry, forestry contractors are market-oriented economic entities, which, in addition to competitiveness in economic terms, are expected by society and forestry experts to be competitive in quality terms (Košir et al. 1994). The performance of harvesting operations strongly influences profitability and service satisfaction for both industries and wood suppliers (Erlandsson et al. 2016). Forestry contractors today need to represent economically and socially sustainable businesses. They must be able to meet the standards of performance and quality required not only by their users, i.e. forest owners and timber industry, but also the society as a whole, while respecting all national and international social and labour rights (Šporčić et al. 2018). Forest owners are responsible for the future stability and quality of forests. However, the stability and quality of forests lies in the hands of the forestry contractors who perform harvesting operations. Only educated, well trained and equipped forestry contractors can meet the needs of forest owners. Successful harvesting contractors are crucial for competitive wood supply, where assessing the success of an individual contractor is not straightforward. A contractor with lower profitability can achieve a high level of personal satisfaction (Erlandsson and Fjeld 2017). How can a forest owner distinguish among different forestry contractors available on the market? Usually, they rely on the opinions and experiences of friends, neighbours and the reputation of the forestry contractor in the local community. For example, in tourism, with over one billion users a year, the first system for the assessment of accommodations was developed more than 60 years ago, while an online search tool with a customer rating (booking.com) was developed 24 years ago. These are well-established and wellreceived assessment systems. The forestry sector is smaller and more traditional, requiring a more complex assessment system. Nevertheless, to support forest owners in the selection of forestry contractors, different systems of assessment have been developed and tested in different countries around the world.

The concept presented in Section 2 shall be transformed into a certification brand, which is currently in the process of registration in Slovenia. The brand (hereinafter referred to as the trademark) is used to promote sustainable forestry service providers and to enhance consumer confidence. In addition, forestry contractors can demonstrate that they achieve higher standards. The main purpose of the trademark is to establish an effective system of evaluation of forestry service providers at minimal cost, thus enabling the MojGozdar trademark to allow smaller forestry service providers to enter a market that today requires a certain and constant level of quality. This will increase the awareness of the importance of quality of services, while at the same time facilitating the marketing of quality forestry services. It also benefits customers and other users of forestry services in raising their awareness, as the services available under the MojGozdar trademark will be monitored on the market with welldefined indicators, which will consequently increase confidence throughout the industry. The approach to the MojGozdar certification trademark is voluntary. The forestry contractor and the certification body sign a cooperation agreement to obtain the MojGozdar expert assessment of the suitability of the forestry contractor. The subject of the contract is the determination of mutual rights and obligations regarding obtaining the expert assessment. The signing of the contract is followed by a support period. The support period of the expert assessment enables:

$\Rightarrow$ presentation of indicators that will enable the provider to fulfil the requirements necessary to obtain the trademark and rating

$\Rightarrow$ support in preparing the online application.

Through the assessment of the suitability of forestry contractors, systems such as MojGozdar contribute to better services on the market. Furthermore, the system contributes to the availability of forestry contractors, given that in MojGozdar developers will also strive to extend the system across the border to neighbouring countries. Quality assessment and quality control over forestry contractors and their ratings will benefit not only private forest owners, but also the companies managing state-owned forests. With customer feedback information on the service quality of state-owned companies, private forests would greatly benefit as well. The MojGozdar web-based system enables its users to exert influence on the assessment of forestry contractors by assessing the quality of their services. Great importance is given to the credibility of assessments, as well as to the prevention of abuses related to the inclusion of the system's users in the rating of the contractors' services. Finally, the MojGozdar system also serves as a tool for the promotion of quality, skilful and reliable forestry contractors. The authors believe that client assessment is, together with independent expert assessment, crucial for the reliable selection of forestry service providers. To bring a system like MojGozdar into widespread use is a challenging task. It is a process that involves not only forest owners who are willing to use the internet and webbased tools, but also policy makers, forest inspectors 
and other users of forests (for recreation and relaxation). At the moment, information on more than 1584 forestry contractors are included in MojGozdar (June 2020), but less than $10 \%$ of them are also included in the process of quality assessment. We are at the »beginning of the road « given that the assessment system was fully in operation in summer 2019.

\section{Conclusions}

Based on the presented results, we can also conclude that such tools are very interesting from a statistical point of view. When the majority of contractors in a country are included in such a system, it will also give a good overall statistic about the number and size of contractor companies as well about the kind of services that they provide. When the system will have been in use for some years more, the statistics will also give trends about forest contractors development.

In conclusion, forestry is heavily dependent on small contractors to carry out harvesting operations. The number of forestry contractors is increasing not only due to organisational changes, but also due to large natural disturbances that have affected forests in the last 5 years (from ice and windstorms to bark beetle attacks). To support forest owners in their forest management and to secure the future stability and quality of forests, new approaches in forestry contractor assessment are needed. MojGozdar is a platform built on specific national conditions, but the idea and the methodology of assessment can be easily transferred to other countries.

\section{Acknowledgments}

The online information system MojGozdar has been developed as part of a national research project entitled »A system for assessing the quality of forestry contractors « funded by the Ministry of Agriculture, Forestry and Food and the Agency for Research of the Republic of Slovenia. The paper was prepared as a part of national research project entitled $»$ Development of indicators and methodology for monitoring of forest contractors « funded by the Ministry of Agriculture, Forestry and Food and the Agency for Research of the Republic of Slovenia. We would like to thank the reviewers for their valuable comments and suggestions, which have improved the quality of the paper.

\section{References}

Adams, W.M., 2006: The future of sustainability: Re-thinking environment and development in the twenty-first century. Report of the IUCN Renowned Thinkers Meeting, January 29-31, $18 \mathrm{p}$.
Assembly, U.N.G., 2006: Resolutions and Decisions Adopted by the General Assembly During Its Sixtieth Session: Volume IIDecisions (September 13 - December 23, 2005). United Nations Publications.

Belbo, H., 2013: Contractor forestry. Proceedings of the 2013 OSCAR workshop held in Honne, Norway, November 11-13, Rapport fra Skog og landskap, 31 p.

Borchert, H., Benker, K., 2015: The economic situation of forest contractors in Bavaria. Proceedings of $48^{\text {th }}$ International Symposium on Forestry Mechanisation - FORMEC »Forest Engineering: Making a positive contribution «, Linz, Austria, October 4-8, 31-34.

European Commission, 2011: A renewed EU strategy 2011-14 for corporate social responsibility. Communication from the Commission to the European Parliament, the Council, the European Economic and Social Committee and the Committee of the Regions, $15 \mathrm{p}$.

Drolet, S., LeBel, L., 2010: Forest harvesting entrepreneurs, perception of their business status and its influence on performance evaluation. Forest Policy and Economics 12(4): 287-298. https:// doi.org/10.1016/j.forpol.2009.11.004

EKVILIB, 2019: Corporate social responsibiliy. Available online: http://www.ekvilib.org/en/corporate-social-responsibility/ (accessed 15. September 2019).

Eriksson, M., 2016: Developing client-supplier alignment in Swedish wood supply. PhD Thesis, Swedish University of Agricultural Sciences, Umeå 2016, 1-91.

Eriksson, M., LeBel, L., Lindroos, O., 2015: Management of outsourced forest harvesting operations for better customer-contractor alignment. Forest Policy and Economics 53: 45-55. https://doi.org/10.1016/j.forpol.2015.01.002

Erlandsson, E., 2013: The Impact of Industrial Context on Procurement, Management and Development of Harvesting Services: A Comparison of Two Swedish Forest Owners Associations. Forests 4(4): 1171-1198. https://doi.org/10.3390/f4041171

Erlandsson, E., 2016: The Triad Perspective on Business Models for Wood Harvesting - Tailoring for Service Satisfaction within Forest Owners Associations. PhD Thesis, Swedish University of Agricultural Sciences, Umeå 2016, 1-62.

Erlandsson, E., Fjeld, D., 2017: Impacts of service buyer management on contractor profitability and satisfaction - a Swedish case study. International Journal of Forest Engineering 28(3): 148-156. https://doi.org/10.1080/14942119.2017.1367235

Erlandsson, E., Fjeld, D., Lidestav, G., 2016: Measuring quality perception and satisfaction for wood harvesting services with a triad perspective. International Journal of Forest Engineering 28(1): 18-33. https://doi.org/10.1080/14942119.2017.1257304

European Commission, 2010: Good practice guidance on the sustainable mobilisation of wood in Europe. MCPFE \& EC \& UNECE/FAO, 75 p. https://doi.org/10.2762/17910

Feil, J.P., 2009: Certification of Forest Contractors (CeFCo). Avaliable online: https://www.nepcon.org/projects/certificationforest-contractors-cefco (accessed 3. November 2019)

Feil, J.P., 2012: Certifitaion of Forest Contractors (CeFCo) Project - Layman's Report. ECO-INNOVATION ECO/08/238998/ SI.532252. European Commission. 
Fischer, W., 1992: Climate protection and international policy: the Rio-conference between global responsibility and national interests. Forschungszentrum Jülich, Zentralbibliothek.

Fogdestam, N., Norin, K., Eriksson, B., 2013: The Golden Logger or how to find, highlight and encourage a good example. Proceedings of the 2013 OSCAR workshop held in Honne, Norway, November 11-13, Rapport fra Skog og landskap, 31 p.

Forest Industry Safety Council, 2014: SafeTree - Contractor certification. Avaliable online: https://safetree.nz/certification (accessed 10. December 2019)

Gole, P.A., 2015: Družbena odgovornost prakse odnosov z javnostmi za vključevanje deležnikov. Journal of Innovative Business and Management 7(2): 1-9.

Häggström, C., 2015: Human Factors in Mechanized Cut-toLength Forest Operations. PhD Thesis, Swedish University of Agricultural Sciences, Umeå 2016, 1-77.

Häggström, C., Kawasaki, A., Lidestav, G., 2013: Profiles of forestry contractors and development of the forestry-contracting sector in Sweden. Scandinavian Journal of Forest Research 28(4): 395-404. https://doi.org/10.1080/02827581.2012.738826

IKGLR, 2018: Execution of works in forests. Avaliable online: http://www.ikglr.gov.si/si/delovna_podrocja/izvajanje_del_v_ gozdovih/ (accessed 4. Februry 2018)

ISO 26000, 2010: Guidance on social responsibility. International Organization for Standardization, Geneva, Switzerland.

Kastenholz, E., Dyduch, C., Fitzgerald, R., Hudson, B., Jaakkola, S., Lidén, E., Monoyios, K., Morat, J., Pasek, F., Sachse, M., Street, W., Lorbach, J., 2011: Guide to good practice in contract labour in forestry. Food and Agriculture Organization of the United Nations, Rome, $61 \mathrm{p}$.

Knez-Riedl, J., 2008: The development of environmental responsibility amongst Slovenian SMEs. International Journal of Entrepreneurship and Small Business 6(1): 103-113. https://doi. org/10.1504/IJESB.2008.017393

Košir, B., Winkler, I., Medved, M., Krajnc, R., Malnar, J., 1994: Urejanje poslovnih razmerij pri gospodarjenju z državnimi gozdovi. Gozdarski inštitut Slovenije, Ljubljana, 55 p.
Lukič, N., 2004: Sustainable development in EU (Trajnostni razvoj v Evropski uniji), Univerza v Ljubljani, Fakulteta za družbene vede, $134 \mathrm{p}$.

Marchi, E., Chung, W., Visser, R., Abbas, D., Nordfjell, T., Mederski, P.S., McEvan, A., Brink, M., Laschi, A., 2018: Sustainable Forest Operations (SFO): A new paradigm in a changing world and climate. Science of The Total Environment 634: 1385-1397. https://doi.org/10.1016/j.scitotenv.2018.04.084

Masiero, M., Andrighetto, N., 2012: Guidelines for the evaluation of sustainability in the wood-energy supply chains. Research Project: Biomass Trade Centers II, WP, 5.

UN, 1987: Report of the World Commission on Environment and Development: Our common future, transmitted to the General Assembly as an annex to document A/42/427-Development and international co-operation: Environment.

Slovenian Forestry Institute, 2017: Web-based information system MyForester (Spletni informacijski sistem MojGozdar). Available online: https://www.mojgozdar.si (accessed 15. August 2019)

Spinelli, R., Magagnotti, N., Facchinetti, D., 2013: Logging companies in the European mountains: an example from the Italian Alps. International Journal of Forest Engineering 24(2): 109-120. https://doi.org/10.1080/14942119.2013.838376

Spinelli, R., Magagnotti, N., Jessup, E., Soucy, M., 2017: Perspectives and challenges of logging enterprises in the Italian Alps. Forest Policy and Economics 80: 44-51. https://doi.org/10.1016/j. forpol.2017.03.006

Šporčić, M., Bakarić, M., Crnić, I., Landekić, M., 2018: Pregled dobre prakse u šumarskom poduzetništvu. Nova meh. šumar. 39: 67-82.

Šporčić, M., Landekić, M., Papa, I., Lepoglavec, K., Nevečerel, H., Seletković, A., Bakarić, M., 2017: Current Status and Perspectives of Forestry Entrepreneurship in Croatia. South-east Eur for 8(1): 21-29. https://doi.org/10.15177/seefor.17-01

Wikipedia, 2019: Sustainable development. https://en.wikipedia.org/wiki/Sustainable_development (February 2019).

(C) 2020 by the authors. Submitted for possible open access publication under the terms and conditions of the Creative Commons Attribution (CC BY) license (http://creativecommons.org/licenses/by/4.0/).

Received: January 31, 2020

Accepted: July 22, 2020
Authors' addresses:

Matevž Triplat, $\mathrm{BSc}^{*}$

e-mail: matevz.triplat@gozdis.si

Nike Krajnc, PhD

e-mail: nike.krajnc@gozdis.si

Slovenian Forestry Institute

Department for forest technique and economics

Večna pot 2

1000, Ljubljana

SLOVENIA

* Corresponding author 